Електронне наукове фахове видання "Ефективна економіка" включено до переліку наукових фахових видань України з питань економіки (Категорія «Б», Наказ Міністерства освіти і науки України від 11.07.2019 № 975) www.economy.nayka.com.ua |№ 1, 2022 | 27.01.2022 p.

DOI: $10.32702 / 2307-2105-2022.1 .8$

УДК 339.173

\title{
Р. Р. Русин-Гриник,
}

доктор філософії, асистент кафедри підприємництва та екологічної експертизи товарів, Національний університет «Львівська політехніка»

ORCID ID: 0000-0003-2895-6437

\section{O.В.Матяи,}

студент кафедри підприємництва та екологічної експертизи товарів, Начіональний університет «Львівська політехніка»

ORCID ID: 0000-0003-3265-8643

\section{ОБГРУНТУВАННЯ ВИБОРУ ФАКТОРІВ, ЩО ВПЛИВАЮТЬ НА РОЗВИТОК ПІДПРИСМНИЦЬКИХ СТРУКТУР НА ОСНОВІ ТЕХНОЛОГІЙ ЕЛЕКТРОННОЇ КОМЕРЦІї}

\author{
R. Rusyn-Hrynyk \\ PhD, Assistant of the Department of Entrepreneurship and Environmental Examination of Goods, \\ Lviv Polytechnic National University \\ O. Matiash \\ Student of the Department of Entrepreneurship and Environmental Examination of Goods, \\ Lviv Polytechnic National University
}

\section{RATIONALE FOR CHOOSING FACTORS AFFECTING THE DEVELOPMENT OF ENTREPRENEURIAL STRUCTURES BASED ON E-COMMERCE TECHNOLOGIES}

У зв'язку з невпинним розвитком інформаційних мереж з'являються й нові суспільні інститути, такі як «електронна комериія». Ефективна діяльність будь-яких підприємств, які використовують технології електронної комериії, базується на прийнятті таких рімень, які відображають вибір факторів, що допоможуть вибрати альтернативні варіанти їх реалізації. Більшість досліджень лише фрагментарно описують фактори, які безпосередньо впливають на розвиток підприємств, щуо використовують у своїи діяльності технології електронної комериії. А також містять лише узагальнені, а не прикладні поради щцодо використання управлінських рішень, щчо стосуються питань технологій електронної комериії. Під час прийняття ефективних управлінських рішень, які будуть формуватися під виливом будь-якого із наведених у статті факторів, незалежно від їх потениіалу, також потрібно враховувати їхню відносну значущість. Важливе місие також займає і характер їх впливу на фінансово-господарську діяльність підприємства, щзо використовує технологій електронної комериії. Під час проведення дослідження, нами виявлено фактори, які безпосередньо вагомо можуть вплинути на розвиток фінансово-господарської діяльності підприємства.

Due to the constant development of information networks, new public institutions, such as " $e$ commerce", are emerging. The effective operation of any enterprise that uses e-commerce technologies is based on making decisions that reflect the choice of factors that will help choose alternatives for their implementation. Effective and successful development of enterprises that use e-commerce technologies in their activities force them to make business decisions based on factor 
analysis. This allows the ranking of alternatives for their implementation. Most studies only fragmentarily describe the factors that directly affect the development of enterprises that use ecommerce technologies in their activities. And also contain only generalized, not applied advice on the use of management decisions related to e-commerce technologies. Their relative importance should also be taken into account when making effective management decisions that will be influenced by any of the factors listed in the article, regardless of their potential. Information about the significance of factors becomes valuable if the analyst has information about the nature of the relationships between factors, possible chain reactions between them, and so on. Given this, we will investigate the structural similarity between the factors, which, in the future, may allow them to cluster. In the process of research the structural similarity of factors influencing the development of business structures based on e-commerce technologies is proved, the obtained primary information used for clustering of factors is used to build a matrix of isomorphic distances. Given the massiveness of this matrix, we will not cite it. Isomorphic values from this matrix indicate which of the factors are most similar in structure. An important place is also occupied by the nature of their impact on the financial and economic activities of the enterprise using e-commerce technologies. During the study, we identified factors that can directly significantly affect the development of financial and economic activities of the enterprise.

Ключові слова: конкурентоспроможність; підприємнищькі структури; управлінські рімення; електронна комерція; значущість факторів.

Key words: competitiveness; business structures; management decisions; e-commerce; significance offactors.

Постановка проблеми. Бурхливий розвиток наявних інформаційних технологій та мережі Інтернет почали відігравати основну роль у різноманітних сферах життєдіяльності, досить суттєво впливають на активізацію суспільної і господарської діяльності та формують рух підприємництва в напрямку світової глобалізації. У зв'язку з невпинним розвитком інформаційних мереж з'являються й нові суспільні інститути, такі як «електронна комерція». Ефективна діяльність будь-яких підприємств, які використовують технології електронної комерції, базується на прийнятті таких рішень, які відображають вибір факторів, що допоможуть вибрати альтернативні варіанти їх реалізації.

Аналіз останніх досліджень та публікацій. Основою для проведення нами досліджень стали праці вітчизняних та зарубіжних науковців, які займалися проблематикою електронного бізнесу, електронної комерції. Особливу уваги ми звернули на таких науковців, як: І. Балабанов, Д. Белл, А. Береза, Н. Дмитрієва, Г. Дункан, Л. Клімченя, О.Кобелев, С. Маловичко, В. Плескач, С. Савельєва, О. Шалева, А. Юрасов. Статистика розвитку торгівлі показує, що електронна комерція стає каталізатором економічного розвитку економіки країни в цілому. Запровадження е-комерції штовхає підприємства до запровадження інновацій у бізнес-процеси й торговельно-економічні відносини.

Проаналізувавши ряд наукової та методичної літератури, ми дійшли висновку, що більшість досліджень лише фрагментарно описують фактори, які безпосередньо впливають на розвиток підприємств, що використовують у своїй діяльності технології електронної комерції. А також містять лише узагальнені, а не прикладні поради щодо використання управлінських рішень, що стосуються питань технологій електронної комерції. Отже, спробуємо класифікувати фактори, які впливають на діяльність підприємства, які використовують технологій електронної комерції.

Метою написання статті є визначення та обгрунтування факторів, які впливають на діяльність підприємства у зв'язку використання ними технологій електронної комерції.

Виклад основного матеріалу. Проаналізувавши ряд наукових праць, ми побачили, що дослідники лише фрагментарно аналізували фактори, що впливають на фінансово-господарську діяльність підприємств, які використовують елементи електронної комерції. А також містять узагальнені рекомендації, що допоможуть керівникам прийняти відповідні управлінських рішення із використанням цих технологій. Ефективний та успішний розвиток підприємств, які у своїй діяльності використовують технології електронної комерції заставляють приймати підприємницькі рішення на основі факторного аналізу. Це дозволяє проведення ранжування альтернативних варіантів для їх реалізації. Під час проведеного експертного дослідження виявлено, що на розвиток підприємницьких структур на основі технологій електронної комерції впливає низка факторів, а саме: рівень кваліфікації персоналу підприємницької структури і укомплектованості кадрами усіх структурних підрозділів; рівень розвитку системи інформаційного забезпечення управління підприємницькою структурою; рівень розвитку системи менеджменту підприємницької структури; рівень розвитку системи логістики підприємницької структури; фінансовий стан підприємницької структури; приналежність пропонованих на ринок товарів до груп еластичного або нееластичного попиту; широта номенклатури та асортименту товарної продукції; рівень розвитку систем маркетингу і реклами; галузева специфіка підприємницької структури; рівень 
конкуренції на ринку, на якому функціонує підприємницька структура; наявність експортної діяльності у підприємницькій структурі; рівень податкового навантаження; репутація підприємницької структури; рівень тінізації діяльності підприємницької структури; форма власності та організаційний тип підприємницької структури; походження капіталу, на основі якого створено підприємницьку структуру (вітчизняний, іноземний, змішаний); рівень інноваційності підприємницької структури.

У табл. 1 наведено результати опитування респондентів. Респондентам пропонувалось призначити факторам бали за шкалою від 10 до 100, де 10 - мінімальна оцінка.

Таблиця 1.

Бальні оцінки, призначені респондентами факторам

\begin{tabular}{|c|c|c|c|c|c|c|c|c|}
\hline \multirow[b]{2}{*}{ ФАКТОРИ } & \multicolumn{8}{|c|}{ РЕСПОНДЕНТИ } \\
\hline & 1 & 2 & 3 & 4 & 5 & 6 & 7 & 8 \\
\hline 1 & 10 & 10 & 20 & 20 & 90 & 20 & 10 & 20 \\
\hline 2 & 20 & 60 & 90 & 20 & 100 & 20 & 40 & 90 \\
\hline 3 & 20 & 40 & 90 & 20 & 10 & 10 & 30 & 90 \\
\hline 4 & 10 & 50 & 100 & 10 & 60 & 60 & 20 & 100 \\
\hline 5 & 60 & 40 & 10 & 60 & 40 & 40 & 10 & 10 \\
\hline 6 & 40 & 20 & 60 & 40 & 20 & 70 & 100 & 40 \\
\hline 7 & 50 & 100 & 40 & 20 & 20 & 60 & 10 & 30 \\
\hline 8 & 40 & 10 & 50 & 10 & 10 & 70 & 60 & 20 \\
\hline 9 & 20 & 60 & 40 & 60 & 60 & 20 & 40 & 10 \\
\hline 10 & 30 & 40 & 20 & 40 & 40 & 20 & 50 & 100 \\
\hline 11 & 10 & 50 & 20 & 50 & 20 & 10 & 40 & 10 \\
\hline 12 & 40 & 20 & 20 & 40 & 100 & 60 & 20 & 60 \\
\hline 13 & 30 & 10 & 10 & 20 & 10 & 40 & 10 & 70 \\
\hline 14 & 20 & 60 & 60 & 30 & 60 & 40 & 20 & 50 \\
\hline 15 & 10 & 40 & 40 & 10 & 50 & 40 & 40 & 40 \\
\hline 16 & 20 & 90 & 100 & 10 & 60 & 60 & 90 & 100 \\
\hline 17 & 50 & 10 & 10 & 60 & 40 & 40 & 10 & 10 \\
\hline
\end{tabular}

Примітка: побудовано на основі проведеного експертного дослідження

Як бачимо, серед 17 факторів, найбільш значущим виявився 16 фактор (66,25 балів), а найменш значущими - 1 і 13 (по 25 балів кожен) (рис.1.).

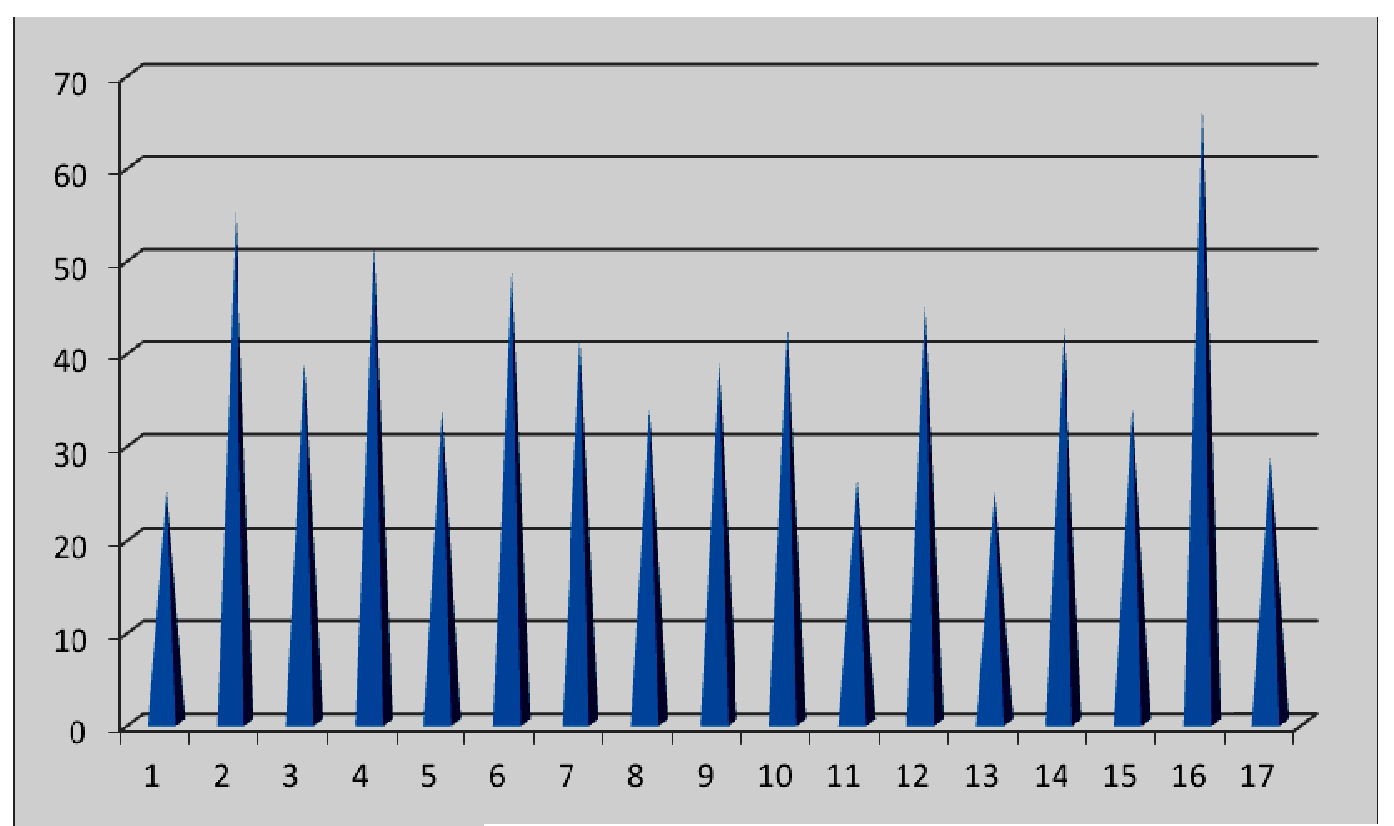

Рис. 1. Відносна значущість факторів, шо впливають на розвиток підприємницьких структур на основі технологій електронної комерції

Примітка: побудовано на основі проведеного експертного дослідження; за вертикаллю - середні значення балів, за горизонталлю - фактори; 1 - 25; 2 - 55; 3 - 38,75; 4 - 51,25; 5 -33,75; 6 - 48,75; 7 - 41,25; 8 33,$75 ; 9-38,75 ; 10-42,5 ; 11-26,25 ; 12-45 ; 13-25 ; 14-42,5 ; 15-33,75 ; 16-66,25 ; 17-28,75$.

Інформація про значущість факторів набуває цінності, якщо аналітик володіє інформацією про характер зв’язків між факторами, можливі ланцюгові реакції між ними тощо. 3 огляду на це, дослідимо 
структурну подібність між факторами, що, в подальшому, можливо, дозволить їх кластеризувати. На основі правил логіки, огляду та аналізу літературних джерел, емпіричних досліджень і проведеного експертного дослідження є підстави стверджувати, що спільним структурним елементом усіх факторів, які впливають на розвиток підприємницьких структур на основі технологій електронної комерції є об’єкт (О), стосовно якого досліджуються ці фактори. Щодо інших структурних елементів, то вони мають бінарну природу. До них належать характер факторів (фактори позитивної $\left(\mathrm{X}_{1}\right)$ або негативної дії $\left(\mathrm{X}_{2}\right)$ ), їхня значущість (значущі $\left(\mathrm{Y}_{1}\right) \mathrm{i}$ незначущі $\left.\left(\mathrm{Y}_{2}\right)\right)$ і приналежність факторів до групи постійно $\left(\mathrm{Z}_{1}\right)$ або тимчасово діючих $\left(\mathrm{Z}_{2}\right)$.

На рис. 2 представлено бінарну структурну модель для аналізу факторів, що впливають на розвиток підприємницьких структур на основі технологій електронної комерції.

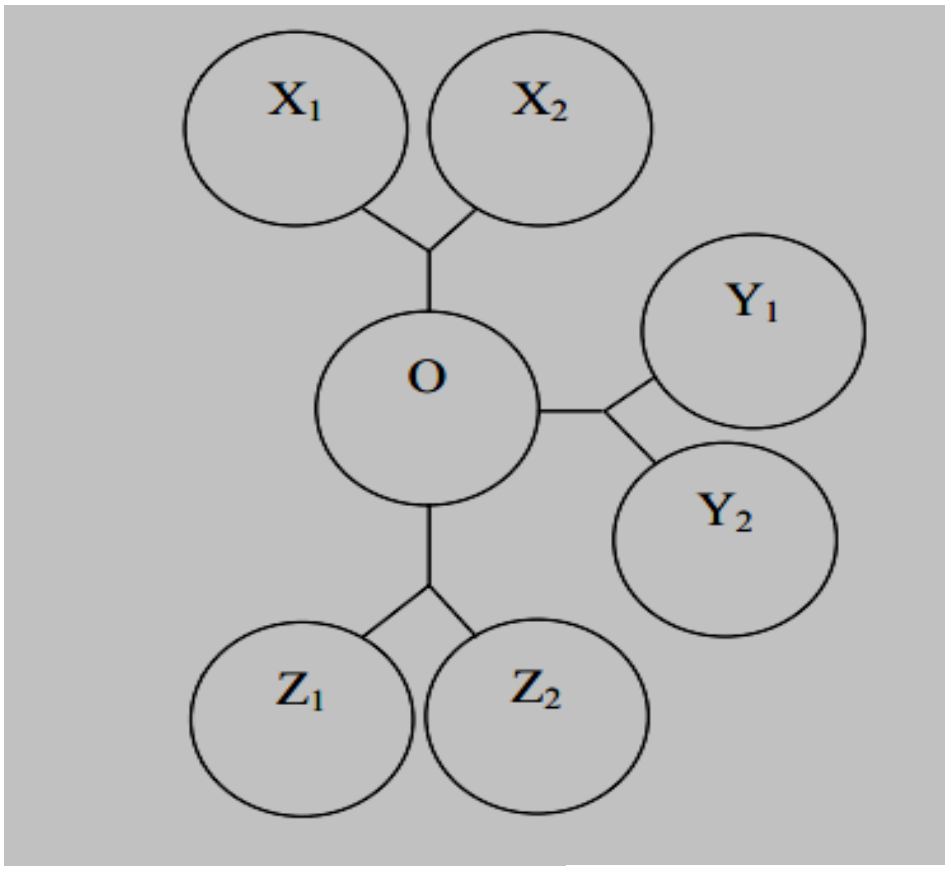

Рис. 2. Бінарна структурну модель для аналізу факторів, що впливають на розвиток підприємницьких структур на основі технологій електронної комерції

Отже, враховуючи те, що у процесі дослідження доведено структурну подібність факторів, які впливають на розвиток підприємницьких структур на основі технологій електронної комерції, то отримана первинна інформація використана для кластеризації факторів використана для побудови матриці ізоморфних відстаней. 3 огляду на масивність цієї матриці наводити іï не будемо. Ізоморфні значення із цієї матриці вказують на те, які з факторів найбільш подібні за структурою.

На основі бінарного порівняння ізоморфних значень можна встановити, які 3 факторів мають найбільший ступінь структурної подібності, а також ідентифікувати фактори ізоморфна відстань між якими найбільшою. Виконавши це завдання отримано такі результати:

Мінімальні ізоморфні відстані:
1) 0,205856 між 1 і 12 факторами;
2) 0,134265 між 2 і 14 факторами;
3) 0,196932 між 3 і 4 факторами;
4) 0,157819 між 4 і 2 факторами;
5) 0,103534 між 5 і 17 факторами;
6) 0,136988 між 6 і 8 факторами;
7) 0,222385 між 7 i 14 факторами;
8) 0,136988 між 8 і 6 факторами;
9) 0,126911 між 9 і 11 факторами;
10) 0,217081 між 10 і 14 факторами;
11) 0,126911 між 11 і 9 факторами;
12) 0,202791 між 12 і 14 факторами;
13) 0,220396 між 13 і 10 факторами;
14) 0,134265 між 14 і 2 факторами;
15) 0,098644 між 15 і 16 факторами;
16) 0,098644 між 16 і 15 факторами;
17) 0,103534 між 17 і 5 факторами. 
Максимальна ізоморфна відстань - 0,222385 - критична точка між 7 і 14 факторами. Значення 0,222385 $€$ критичним, тому саме відстань між 7 і 17 факторами розбиває загальну сукупність досліджуваних факторів на різні групи, тобто кластери (рис. 3)

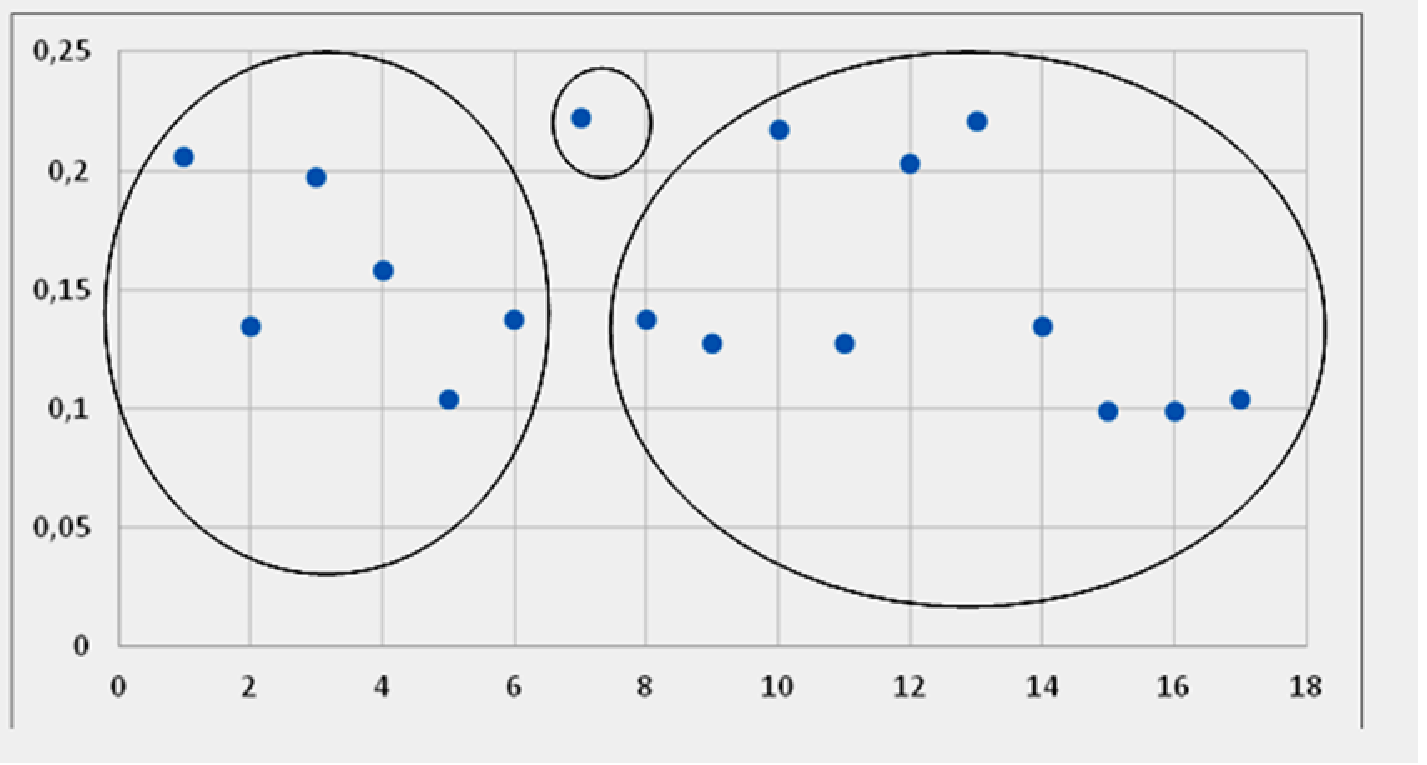

Рис. 3. Кластери факторів

Примітки: Горизонталі - порядкові номери факторів; вертикаль - ізоморфні відстані

3 позиції інформаційно-аналітичної корисності отриманої інформації про наявність побудованих кластерів дані відомості $\epsilon$ необхідними але недостатніми для прийняття обгрунтованих управлінських підприємницьких рішень. Окрім утворених кластерів необхідною є також інформація про лінійні структурні зв'язки між факторами. Знаючи лінійні зв'язки можна передбачити траєкторію зміни умов, в яких відбуватиметься реалізація прийнятого рішення. В даному випадку під траєкторією зміни умов розуміємо динаміку взаємовпливу факторів один на одного, що виникає внаслідок управлінського впливу на один або більше факторів.

За допомогою clast_izomorf_trec сформовано матрицю відстаней між утвореними ланцюжками факторів (табл. 2).

Таблиця 2.

Матриця відстаней між ланцюжками

\begin{tabular}{|c|c|c|c|c|c|c|c|}
\hline & 1 & 2 & 3 & 4 & 5 & 6 & 7 \\
\hline 1 & 0 & 0,202791 & 0,285997 & 0,244971 & 0,305272 & 0,260457 & 0,230989 \\
\hline & $\mathbf{( 0 ; 0 )}$ & $(12 ; 14)$ & $(12 ; 4)$ & $(12 ; 17)$ & $(12 ; 6)$ & $(12 ; 9)$ & $(12 ; 15)$ \\
\hline 2 & $\mathbf{0 , 2 0 2 7 9 1}$ & 0 & 0,157819 & 0,274594 & 0,25108 & 0,188833 & 0,138473 \\
\hline & $(12 ; 14)$ & $\mathbf{( 0 ; 0 )}$ & $(2 ; 4)$ & $(7 ; 5)$ & $(10 ; 6)$ & $(14 ; 9)$ & $(14 ; 15)$ \\
\hline 3 & 0,285997 & $\mathbf{0 , 1 5 7 8 1 9}$ & 0 & 0,431164 & 0,317502 & 0,339049 & 0,177567 \\
\hline & $(12 ; 4)$ & $(2 ; 4)$ & $\mathbf{( 0 ; 0 )}$ & $(4 ; 5)$ & $(3 ; 6)$ & $(4 ; 9)$ & $(4 ; 16)$ \\
\hline 4 & 0,244971 & 0,274594 & $\mathbf{0 , 4 3 1 1 6 4}$ & 0 & 0,344656 & 0,251994 & 0,369322 \\
\hline & $(12 ; 17)$ & $(7 ; 5)$ & $(4 ; 5)$ & $\mathbf{( 0 ; 0 )}$ & $(5 ; 6)$ & $(5 ; 9)$ & $(5 ; 15)$ \\
\hline 5 & 0,305272 & 0,25108 & 0,317502 & $\mathbf{0 , 3 4 4 6 5 6}$ & 0 & 0,282243 & 0,224757 \\
\hline & $(12 ; 6)$ & $(10 ; 6)$ & $(3 ; 6)$ & $(5 ; 6)$ & $\mathbf{( 0 ; 0 )}$ & $(6 ; 9)$ & $(6 ; 15)$ \\
\hline 6 & 0,260457 & 0,188833 & 0,339049 & 0,251994 & $\mathbf{0 , 2 8 2 2 4 3}$ & 0 & 0,242362 \\
\hline & $(12 ; 9)$ & $(14 ; 9)$ & $(4 ; 9)$ & $(5 ; 9)$ & $(6 ; 9)$ & $\mathbf{( 0 ; 0 )}$ & $(9 ; 15)$ \\
\hline 7 & 0,230989 & 0,138473 & 0,177567 & 0,369322 & 0,224757 & $\mathbf{0 , 2 4 2 3 6 2}$ & 0 \\
\hline & $(12 ; 15)$ & $(14 ; 15)$ & $(4 ; 16)$ & $(5 ; 15)$ & $(6 ; 15)$ & $(9 ; 15)$ & $(\mathbf{0} ; \mathbf{0})$ \\
\hline
\end{tabular}

Примітка: побудовано на основі проведеного експертного дослідження

Бінарно порівнявши ізоморфні відстані між ланцюжками виявлено найбільшу структурну подібність між факторами, які належать до різних ланцюжків. Йдеться про ізоморфні відстані між 12 i14 факторами, 2 і 4 , 4 i5, 5 і 6, 6 i9, 9 і 15. Внаслідок цього встановлено, що існують лінійні зв’язки між: 1 і 2 ланцюжками. Мінімальна ізоморфна відстань - 0,202791; 2 і 7 ланцюжками. Мінімальна ізоморфна відстань - 0,138473; 3 і 2 ланцюжками. Мінімальна ізоморфна відстань - 0,157819; 4 і 1 ланцюжками. Мінімальна ізоморфна відстань 0,244971; 5 і 7 ланцюжками. Мінімальна ізоморфна відстань - 0,224757; 6 і 2 ланцюжками. Мінімальна ізоморфна відстань - 0,188833; 7 і 2 ланцюжками. Мінімальна ізоморфна відстань - 0,138473. 
Маючи ці дані побудуємо дендрит факторів, що впливають на розвиток підприємницьких структур на основі технологій електронної комерції (рис. 4).

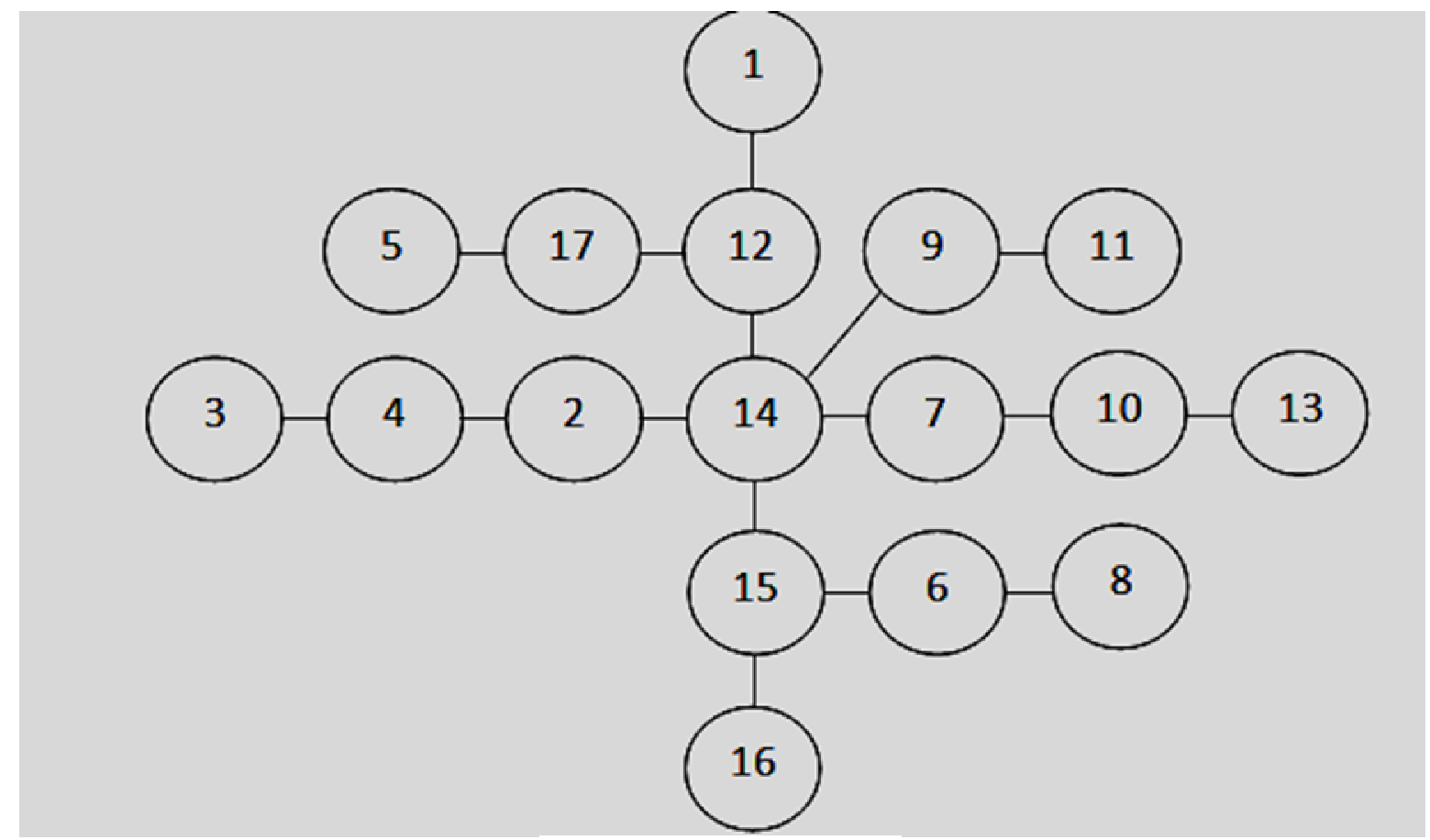

Рис. 4. Дендрит факторів

Отож, проаналізуємо цей дендрит як інструментарій для обгрунтування управлінських підприємницьких рішень. Як бачимо, із загальної сукупності факторів 1,3, 5, 8, 11, 13 і 16 лінійно пов'язані лише 3 одним із факторів, тому вони характеризуються найменшим потенціалом впливу на траєкторію зміни умов, в яких відбуватиметься реалізація того чи іншого прийнятого управлінського підприємницького рішення. На противагу цій групі факторів 12, 14 і 15 фактори мають найбільший потенціал впливу на траєкторію зміни умов, оскільки 14 фактор лінійно пов'язаний із п'ятьма факторами, а кожен із 12 і 14 факторів, пов'язаний із трьома іншими факторами. Інші фактори $(2,4,6,7,9,10,17)$ мають не високий, проте суттєвий потенціал впливу на траєкторію зміни умов, в яких відбуватиметься реалізація того чи іншого прийнятого управлінського підприємницького рішення.

Висновки. Під час прийняття ефективних управлінських рішень, які будуть формуватися під впливом будь-якого із цих факторів, незалежно від їх потенціалу, також потрібно враховувати їхню відносну значущість. Важливе місце також займає і характер їх впливу на фінансово-господарську діяльність підприємства, що використовує технологій електронної комерції. Під час проведення дослідження, нами виявлено фактори, які безпосередньо вагомо можуть вплинути на розвиток фінансово-господарської діяльності підприємства. Щодо перспектив подальшого дослідження, то потрібно звернути свою увагу на дослідженні кластиризації факторів впливу на діяльність підприємства, що використовує технології електронної комерції.

\section{Література.}

1. Sumets A., Serbov M., Skrynkovskyy R., Faldyna V., Satusheva K. Analysis of influencing factors on the development of agricultural enterprises based on e-commerce technologies. Agricultural and Resource Economics. 2020. Vol. 6, No. 4. P. 211-231.

2. Жильченкова В.В., Хацинская В.А. Актуальные проблемы формирования и реализации кадровой политики на предприятии. Ефективна економіка. 2012. № 10. URL: http://www.economy.nayka.com.ua $/ ? \mathrm{op}=1 \& \mathrm{z}=1432$ (дата звернення 28.12.2021).

3. Устенко А.О. Система управління підприємством. Вісник Прикарпатського університету. Економіка. 2014. №10. С. 96-103.

4. Пальчик I. М. Логістичне управління підприємством - теоретико-методичний аспект. Ефективна економіка. 2014. № 10. URL: http://www.economy. nayka.com.ua (дата звернення 30.12.2021).

5. Базілінська. О.Я. Фінансовий аналіз: теорія та практика: навч. посіб. Київ: Центр учбової літератури, 2012. 328 с.

6. Апопій В. В. Комерційна діяльність: навч.посіб. Київ: Знання. 2008. 558 с.

7. Джефкінс Ф. Реклама: практ. посіб. пер. 3 4-го англ. вид. / за ред. Д. Ядіна. Київ: Т-во “Знання”, 2001. 456 с.

8. Савчук О. Системний підхід до аналізу конкурентоспроможності промислового виробництва. Економіст. 2001. № 12. С. 58-61.

9. Водачек Л., Водачкова О. Стратегія управління інноваціями на підприємстві. Москва : Економіка, 1989. 325 с. 


\section{References.}

1. Sumets, A., Serbov, M., Skrynkovskyy, R., Faldyna, V. and Satusheva, K. (2020), "Analysis of influencing factors on the development of agricultural enterprises based on e-commerce technologies", Agricultural and Resource Economics, vol. 6, no. 4, pp. 211-231.

2. Zhilchenkova, V.V. and Khatsinskaya, V.A. (2012), "Actual problems of formation and implementation of personnel policy at the enterprise", Efektyvna ekonomika, [Online], vol. 10, available: http://www.economy.nayka.com.ua /?op=1\&z=1432 (Accessed 28.12.2021).

3. Ustenko, A.O. (2014), "Enterprise management system", Visnyk Prykarpatskogo universytetu. Ekonomika. vol. 10, pp. 96-103.

4. Palchyk, I. M. (2014), "Logistics company management - theoretical and methodological aspect", Efektyvna ekonomika, [Online], vol. 10, available: http://www.economy. nayka.com.ua (Accessed 30.12.2021).

5. Bazilins'ka, O. Ya. (2012), Finansovyj analiz: teoriia ta praktyka [Financial Analysis: Theory and Practice], Tsentr uchbovoi literatury, Kyiv, Ukraine.

6. Apopij, V. V. (2008), Komercijna diyalnist [Commercial activity], Znannya, Kyiv, Ukraine.

7. Jeffkins, F. (2001), Reklama [Advertising], T-vo “Znannya”, Kyiv, Ukraine.

8. Savchuk, O. (2001), "System approach to the analysis of the competitiveness of industrial production", Ekonomist, vol. 12, pp. 58-61.

9. Vodachek L. and Vodachkova O. (1989), Stratehiia upravlinnia innovatsiiamy na pidpryiemstvi [Strategy of innovation management at the enterprise], Economica, Moscow, Russian.

Стаття надійшла до редакиії 11.01.2022 p. 